\title{
Ballistic Performance of Mallow and Jute Natural Fabrics Reinforced Epoxy Composites in Multilayered Armor
}

\author{
Lucio Fabio Cassiano Nascimento ${ }^{*}$, Luis Henrique Leme Louro ${ }^{a}$, Sergio Neves Monteiro ${ }^{a}$, Alaelson Vieira \\ Gomes $^{a}$, Rubens Lincoln Santana Blazutti Marçal ${ }^{a}$ Édio Pereira Lima Júnior ${ }^{a}$, Jean Igor Margem ${ }^{b}$ \\ ${ }^{a}$ Seção de Engenharia Mecânica e de Materiais, Instituto Militar de Engenharia - IME, Praça General \\ Tibúrcio, 80, CEP 22290-270, Urca, Rio de Janeiro, RJ, Brazil \\ ${ }^{b}$ Institutos Superiores de Ensino do CENSA - ISECENSA; Rua Salvador Correa, 139, CEP 28035-310, \\ Campos dos Goytacazes, RJ, Brazil
}

Received: December 07, 2016; Revised: July 10, 2017; Accepted: September 04, 2017

\begin{abstract}
Natural fiber reinforced polymer composites have recently been investigated as a component of multilayered armor system (MAS). These composites were found to present advantages when replacing conventional high strength synthetic aramid fabric laminate composite (Kevlar ${ }^{\mathrm{TM}}$, with same thickness, as MAS second layer. Continuous and loose natural fibers were up to now mostly used to reinforce these ballistic composites. Only two natural fabrics reinforced polymer composite were so far used with same purpose. Therefore, this work investigated the possibility of substituting $\operatorname{Kevlar}^{\mathrm{TM}}$ for three other natural fabrics, based on mallow and jute fibers, as reinforcement of epoxy composites. Fabrics made of either pure mallow, or $70 \%$ mallow $/ 30 \%$ jute or $50 \%$ mallow $/ 50 \%$ jute fibers were separately mixed with epoxy to produce laminate composite plates. These plates were set as second layer of $\mathrm{Al}_{2} \mathrm{O}_{3} / \mathrm{Nb}_{2} \mathrm{O}_{5}$ front ceramic MAS, that were ballistic tested against relatively high energy $7.62 \mathrm{~mm}$ ammunition. Indentation depth values caused by the bullet penetration in clay witness, simulating human body behind the MAS, were always found to be below the safety standard limit. These indentation values were similar to those obtained in MAS with Kevlar ${ }^{\mathrm{TM}}$ as second layer. However, significant economical advantages favor the investigated natural fabric composites over the synthetic Kevlar.
\end{abstract}

Keywords: Mallow fabric, Mallow/Jute fabric, epoxy composite, ballistic test, multilayered armor.

\section{Introduction}

Synthetic high strength fibers, such as glass, carbon and aramid have, from past decades, been successfully used as reinforcement of polymer composites in several engineering areas ${ }^{1}$. In recent decades, however, polymer composites reinforced with natural fibers, mainly those lignocellulosic obtained from plants, are not only being extensively investigates ${ }^{2-11}$ but also replacing the synthetic fibers composites in industrial application related to sectors such as civil construction furniture, commodity and automotive ${ }^{12-14}$. Güven et $\mathrm{a}^{11}$ indicated that a escalating number of publications on natural fiber composites occurred in the last two decades. Indeed, the number of papers with keyword "natural fiber composite" increased exponentially from 3 in 1990 to 686 articles in 2014. In particular, investigations on the ballistic performance of natural fiber composites are, since 2001, also following this tendency ${ }^{15-23}$.

More recently, specific works ${ }^{18-23}$ were published on the ballistic performance of natural fibers reinforced polymeric composites. The ballistic performance was evaluated in standard tests ${ }^{24}$ against high energy $7.62 \mathrm{~mm}$ ammunition by measuring the depth of indentation produced in clay witness simulating a human body behind the MAS.

*e-mail: lucio_coppe@yahoo.com.br
Curaua $^{20,23}$, bamboo $^{19}$ and sisal ${ }^{21}$ fibers composites were tested as components of a multilayered system (MAS) with a front ceramic Other works on MAS and related mechanisms of ballistic protection have been presented since last decade ${ }^{25-26}$. In addition to loose and continuous natural fibers in the composite $^{19-22}$, natural fabrics, made of jute ${ }^{18}$ and ramie ${ }^{22}$ fibers, reinforced polymer matrix composites were also similarly investigated. All these specific works concluded that natural fiber or natural fabric composites present a ballistic performance comparable to the conventional aramid fabric laminate composite ${ }^{27}$, Kevlar ${ }^{\mathrm{TM}}$, as MAS second layer with same thickness.

This surprising result of similar ballistic performance of natural fiber/fabric composites in comparison with the much stronger Kevlar ${ }^{\mathrm{TM}}$ was explained by an equally efficient mechanism of ceramic/bullet fragments capture ${ }^{24,28}$. Economical advantage based on the much expensive Kevlar ${ }^{\mathrm{TM}}$ favors the possible use of natural fiber/fabric composites. The fact that only two types of natural fabric composites were ballistic tested up to now ${ }^{18,22}$ motivated this investigation.

Therefore, the present work evaluated the ballistic performance of three other natural fabrics, both in amount of $30 \mathrm{vol} \%$, reinforcing an epoxy matrix. The fabrics were made from either pure mallow, or 70 mallow/30 jute or 50 
mallow/50 jute fibers. These composites were used as MAS second layer and ballistic tested as per NIJ standard ${ }^{24}$.

\section{Materials and Methods}

The mallow fiber, obtained from a plant of the mallowceous species (Urena lobata, Linn), was supplied by the Brazilian Companhia Textil Castanhal do Pará. The pure 100\% mallow fabric (simple weft - $329 \mathrm{~g} / \mathrm{m}^{2}$ was manually threaded and simple-weaved by an Amazonian native community. The cost was estimated in US\$9.41/kg. Figure 1 illustrates the mallow plant as well as its fibers and investigated pure fabric.
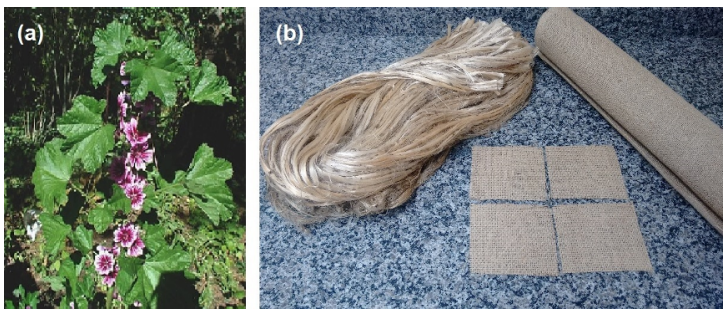

Figure 1. (a) Mallow plant; (b) Mallow fiber, hybrid and pure fabric.

The hybrid 70 mallow $/ 30$ jute (simple weft - 329g/m² and 50 mallow $/ 50$ jute (arraiolo weft $-704 \mathrm{~g} / \mathrm{m}^{2}$ fabrics, Figure 1b, were directly acquired from the same firm (US\$ $9.41 / \mathrm{kg}$ and US $\$ 5.57 / \mathrm{kg}$ respectively) as one of its available product.

The epoxy used as composite matrix was a diglycidyl ether of the bisphenol-A (DGEBA) resin hardened with triethylene tetramine (TETA), Dow Chemical produced, and supplied by the Brazilian firm Resinpoxy (US\$23.50/kg).

The MAS front ceramic was fabricated at the Military Institute of Engineering (IME) laboratory. Both $\mathrm{Al}_{2} \mathrm{O}_{3}$ powder, supplied by Treibacher Schleifmittel as commercial pure (US\$ $1.59 / \mathrm{kg}$ ) and $4 \mathrm{wt} \% \mathrm{Nb}_{2} \mathrm{O}_{5}$ powder, supplied by the Brazilian firm CBMM as 99\% pro-analysis (US\$ 16.13/ $\mathrm{kg}$ ), were mixed in a ball-mill for 8 hours and sieved in a 42 mesh. Sintering of $10 \mathrm{~mm}$ thick hexagonal tiles with $31 \mathrm{~mm}$ of side dimensions was carried out at $1400^{\circ} \mathrm{C}$ for 3 hours under air in a model FF 1700 INTI furnace. The MAS second layer composites were fabricated, for each different fabric, as $10 \mathrm{~mm}$ in thickness square, $150 \mathrm{~mm}$ sides, plate.

Fabrication started with square pieces of fabric with same $150 \mathrm{~mm}$ sides being layed down in a metallic mold. Still fluid DGEBA resin mixed with phr 13 stoichiometric fraction of TETA was poured onto each layer of fabric. A pressure of about $3 \mathrm{MPa}$ was then applied to the mold. The laminate fabric composite plate was cured at room temperature for 24 hours still under pressure.

The MAS back layer was a $5 \mathrm{~mm}$ thick 5052-H34 aluminum alloy sheet with same 150x150 mm side dimensions, supplied by the Brazilian firm Metalak (US\$ 11.24/kg). The complete MAS target' was set up by bonding the three layers (ceramic, composite and aluminum) with a Sikaflex(tm) adhesive from the Brazilian firm Sika Co. Before ballistic test, a block of standard ${ }^{24}$ treated clay witness was placed behind the MAS in direct contact with the aluminum back layer. The clay was a commercially available CORFIX ${ }^{\mathrm{TM}}$ plastiline. Figure 2 shows a schematic view of a complete MAS put together with the clay witness. In this figure it is also shown an actual MAS with pure (100\%) mallow fabric composite as second layer.
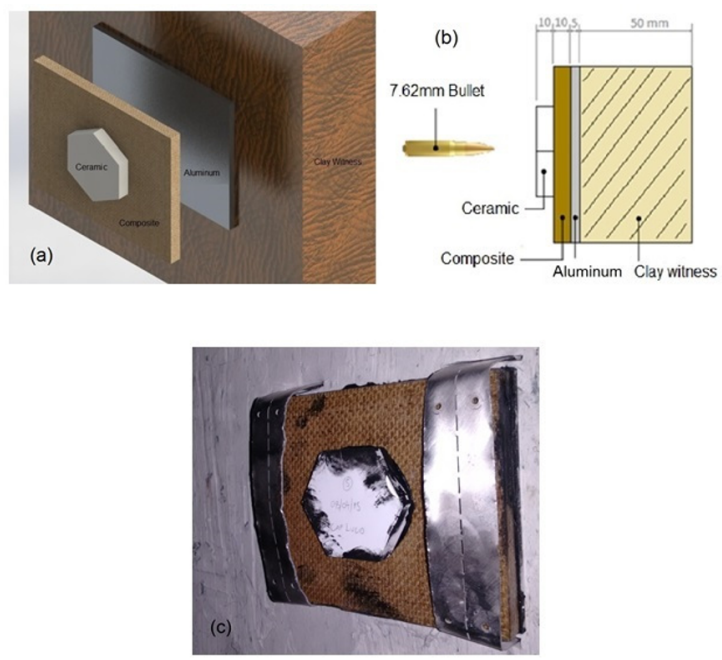

Figure 2. (a) Schematic of a complete MAS, (b) Thickness layers and (c) Actual MAS with pure mallow fabric composite as second layer.

Ballistic tests were carried out at the Brazilian Army Shooting range facility, Centro de Avaliações do Exército, CAEX, located in the Marambaia peninsula, Rio de Janeiro. Figure 3 shows the schematic arrangement for ballistic tests in a CAEX shooting tunnel. In this figure it is also shown, as inserts, two actual MASs with 70 mallow / 30 jute and 50 mallow / 50 jute fabric composite used as second layer.

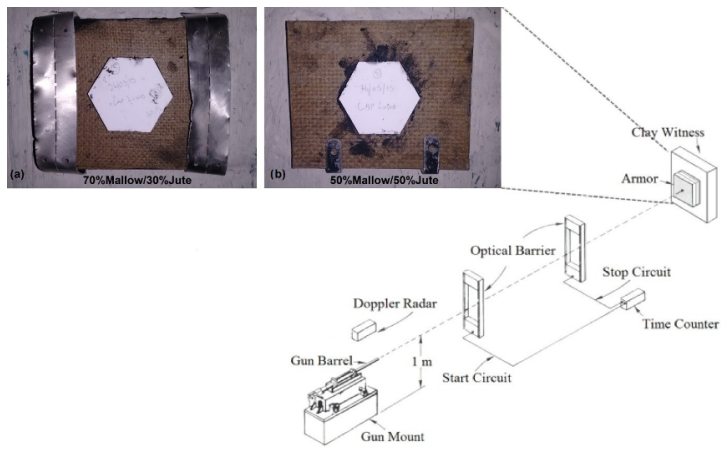

Figure 3. Schematic arrangement of the ballistic test. Insert of actual MAS with front hexagonal ceramic followed by hybrid (a) 70 mallow / 30 jute; (b) 50 mallow / 50 jute fabric composite and backed by aluminum sheet in direct contact with clay witness.

In this figure, the MAS target was positioned by spring clamps to a steel frame. The center of the MAS target was sighted with a laser beam coupled to the gun barrel at a distance 
of $15 \mathrm{~m}$. A minimum of 10 tests was conducted for MAS with distinct fabric composites, using class III $7.62 \times 51 \mathrm{~mm}$ commercial ammunition with $9.7 \mathrm{~g}$ copper bullet propelled from the gun barrel shown in Figure 3. The variation of the bullet velocity was continuously measured by the optical barriers and by a Doppler radar also schematically shown in Figure 3. In average, the bullet leaves the gun barrel at $870 \mathrm{~m} / \mathrm{s}$ and strikes the target at $845 \mathrm{~m} / \mathrm{s}$. This corresponds to an average impact energy of $34 \mathrm{~kJ}$. After bullet impact, the indentation in the clay witness, simulating a trauma in a human body, was measured with a model Q4X Banner laser sensor, as illustrated in Figure 4.
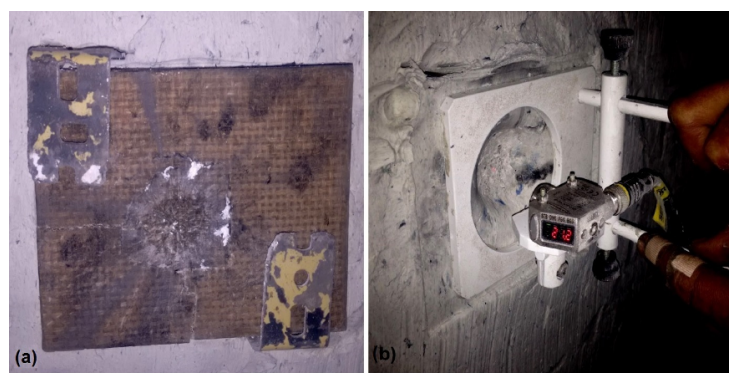

Figure 4. (a) Indentation depth in the clay witness caused by the bullet impact on MAS after ballistic impact. (b) Measurement with Laser sensor caliper, model Q4X by Banner manufacturer.

Samples of the fabric composites, fractured after the ballistic tests, were analysed by scanning electron microscopy (SEM) in a model QUANTA FEG 250 FEI microscopy operating at $20 \mathrm{KV}$ with secondary electrons.

\section{Results and Discussion}

The main result in this work was that in all ballistic tests, with a MAS as target, the $7.62 \mathrm{~mm}$ bullet failed to complete perforate the clay witness. Only partial penetration occurred in association with an indentation like that illustrated in Figure 4.
Table 1 presents values of indentation depth measured in MAS with distinct fabric composites as second layer. In this table it is also shown the average indentation depth of similar MAS, with Kevlar ${ }^{\mathrm{TM}}$ as second layer, reported elsewhere ${ }^{21,23}$.

The reader may find slightly different values for MAS with Kevlar $^{\mathrm{TM}}$ in other publications ${ }^{18-23,29}$. The reason is the independent ballistic tests performed in each one. However, all results are similar within the variance analysis (ANOVA).

As presented in Table 2, the values of indentation depth for the three MASs are the same within the experimental precision, because ANOVA value of $F=1.40$ is smaller than the tabulated 2.87 value.

A specific mechanism of fragment capture mechanism based on incrustation, Van der Waals forces and electrostatic charges ${ }^{30}$ might explain the similar behavior of natural fabric composites as compared to the much stronger Kevlar ${ }^{\mathrm{TM}}$ as MAS second layer. Figure 5 shows SEM micrographs of the fractured composites after the ballistic test. In this figure one should notice the small white ceramic particles that were captured by the fabric composites, Figure 5(a), (c) and (d), covering their fractured surfaces. The ceramic nature of these particles is revealed by the EDS composition in Figure 5(b).

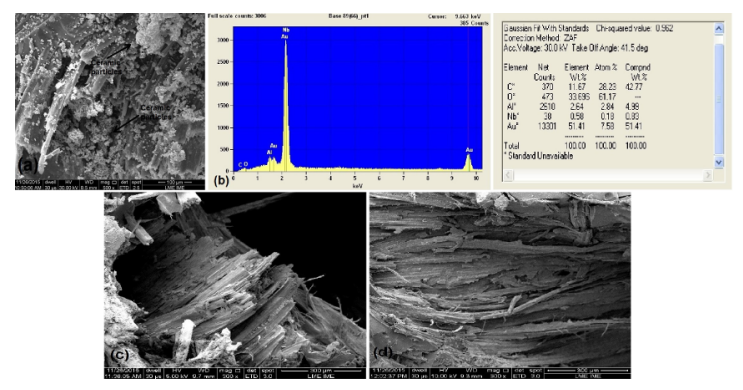

Figure 5. SEM micrographs of the fractured composites after the ballistic test. (a) $100 \%$ mallow fabric (b) EDS of $100 \%$ mallow fabric, (c) $70 \%$ mallow $/ 30 \%$ jute fabric and (d) $50 \%$ mallow $/ 50 \%$ jute fabric.

Table 1. Average depth of indentation depth in the clay witness after bullet impact in MASs with distinct natural fabrics.

\begin{tabular}{lcc}
\hline MAS with second layer with 10mm of thickness & Indentation depth $(\mathrm{mm})$ & Reference \\
\hline Pure mallow fabric reinforced epoxy composite & $21.5 \pm 1.6$ & PW $^{\mathrm{a}}$ \\
70 mallow/30 jute fabric reinforced epoxy composite & $23.2 \pm 2.4$ & $\mathrm{PW}^{\mathrm{a}}$ \\
50 mallow/50 jute fabric reinforced epoxy composite & $23.7 \pm 2.4$ & $\mathrm{PW}^{\mathrm{a}}$ \\
Pure jute fabric reinforced epoxy composite & $20.7 \pm 3.1$ & 18 \\
KevlarTM: 18 plies of aramid fabric with 5\% polychloroprene & $22.7 \pm 2.8$ & 21,23 \\
\hline
\end{tabular}

aPresent work.

Table 2. Variance analysis for ballistic tests with MAS having different second layers.

\begin{tabular}{lccccc}
\hline Causes of variation & DF & Sum of squares & Middle square & F calculated & $\begin{array}{c}\text { F critical } \\
\text { (tabulated) }\end{array}$ \\
\hline Treatments & 4 & 22.77 & 5.69 & 1.40 & 2.87 \\
Residue & 20 & 81.07 & 4.05 & & \\
Total & 24 & 103.84 & & & \\
\hline
\end{tabular}


Table 3. Evaluation of weight and cost of the different multilayered armors.

\begin{tabular}{|c|c|c|c|c|c|}
\hline Armor component & Volume $\left(\mathrm{cm}^{3}\right)$ & Density $\left(\mathrm{g} / \mathrm{cm}^{3}\right)$ & Weight (kgf) & $\begin{array}{c}\text { Price per kg (US } \\
\text { dollars) }\end{array}$ & $\begin{array}{l}\text { Component cost } \\
\text { (US dollars) }\end{array}$ \\
\hline $\mathrm{Al}_{2} \mathrm{O}_{3}$ ceramic tile & 225 & 3.72 & 0.837 & 33.00 & 27.62 \\
\hline Aramid fabric plies & 225 & 1.44 & 0.324 & 63.60 & 20.61 \\
\hline $\begin{array}{l}100 \% \text { Mallow } \\
\text { composite plate }\end{array}$ & 225 & 1.19 & 0.268 & $\begin{array}{c}\text { Fiber } 9.41(30 \%) \\
\text { Epoxy } 23.50(70 \%)\end{array}$ & 5.17 \\
\hline $\begin{array}{l}70 \% \text { Mallow } / 30 \% \\
\text { Jute composite } \\
\text { plate }\end{array}$ & 225 & 1.18 & 0.266 & $\begin{array}{c}\text { Fiber } 9.41(30 \%) \\
\text { Epoxy } 23.50(70 \%)\end{array}$ & 5.13 \\
\hline $\begin{array}{l}50 \% \text { Mallow } / 50 \% \\
\text { Jute composite } \\
\text { plate }\end{array}$ & 225 & 1.17 & 0.263 & $\begin{array}{c}\text { Fiber } 5.57(30 \%) \\
\text { Epoxy } 23.50(70 \%)\end{array}$ & 4.77 \\
\hline $\begin{array}{l}5052 \mathrm{H} 34 \\
\text { aluminum sheet }\end{array}$ & 112.5 & 2.70 & 0.304 & 11.24 & 3.42 \\
\hline \multicolumn{2}{|c|}{$\begin{array}{l}\% \text { of decrease of weight (using 100\% } \\
\text { Mallow fabric composite) }\end{array}$} & 3.82 & \multicolumn{2}{|c|}{$\begin{array}{l}\% \text { of decrease of cost (using } 100 \% \\
\text { Mallow fabric composite) }\end{array}$} & 29.89 \\
\hline \multicolumn{2}{|c|}{$\begin{array}{l}\% \text { of decrease of weight (using } 70 \% \\
\text { Mallow } 30 \% \text { Jute fabric composite) }\end{array}$} & 3.96 & \multicolumn{2}{|c|}{$\begin{array}{l}\% \text { of decrease of cost (using } 70 \% \\
\text { Mallow/30\% Jute fabric composite) }\end{array}$} & 29.97 \\
\hline \multicolumn{2}{|c|}{$\begin{array}{l}\% \text { of decrease of weight (using } 50 \% \\
\text { Mallow/50\% Jute fabric composite) }\end{array}$} & 4.16 & \multicolumn{2}{|c|}{$\begin{array}{l}\% \text { of decrease of cost (using } 50 \% \\
\text { Mallow/50\% Jute fabric composite) }\end{array}$} & 30.67 \\
\hline
\end{tabular}

\subsection{Economical analysis}

Cost analysis strongly favored the 30 vol\% mallow and hybrid mallow/jute fabric reinforced epoxy composite. Table 3 presents a weight and cost analysis based on density obtained from experimental measurements and current prices (November, 2016). The calculated face area of the ceramic plates was considered to cover the whole $150 \mathrm{x}$ $150 \mathrm{~mm}$ (Fig. 3) surface of the MAS target. As shown in Table 3, substituting Kevlar $^{\mathrm{TM}}$ for natural fabric with 30 vol\% mallow, hybrid mallow/jute $(70 / 30 \mathrm{wt} \%)$ or hybrid mallow/jute $(50 / 50 \mathrm{wt} \%)$ fabric reinforced epoxy composite creates only a modest weight decrease around $4 \%$. On the other hand, this substitution represents about $30 \%$ reduction in cost. Therefore, a multilayer armor system with $30 \mathrm{vol} \%$ pure mallow or hybrid mallow/jute (70/30 or 50/50 wt\%) fabric epoxy composites, as compared with Kevlar ${ }^{\mathrm{TM}}$, provides the same technical advantages in terms of ballistic performance, lightness, durability and integrity. However, in addition to these advantages, they are all associated with a much lower cost.

\section{Conclusions}

- The MASs with second layer reinforced with either $100 \%$ mallow fabric, or 70 mallow/30 jute or 50 mallow/50 jute fabric meet the requirements of standard N.I.J. $0101.06^{24}$, since the average indentation obtained on the clay witness, after the ammunition impact $7.62 \mathrm{~mm}$, was lower than $44 \mathrm{~mm}$. Therefore, they can be considered as a suitable material for use in ballistic shielding MAS second layer.

- The main failure mechanism verified by both visual and SEM analysis after the ballistic impact was layer delamination, which together with capture of front ceramic fragments, allow the absorption of much of the kinetic energy coming from the projectile and the shards of the ceramic front layer.

- By means of the analysis of variance it was verified that there is no significant difference between the mean values of indentation in MASs with a second layer of either $100 \%$ mallow fabric, or $100 \%$ jute fabric, or 70 mallow/30 jute or 50 mallow/50 jute fabrics as well as aramid fabric $\left(\operatorname{Kevlar}^{\mathrm{TM}}\right.$. The similarity of mallow and jute fabrics in applications as reinforcement of composites for ballistic purpose was confirmed and found comparable to the Kevlar ${ }^{\mathrm{TM}}$ fabric, which is the material traditionally used in armors for personal ballistic protection.

- The 30\% vol mallow and hybrid mallow/jute fabric (70/30 or $50 / 50 \mathrm{wt} \%$ ) epoxy composite is much less expensive than the aramid fabric, representing a reduction around of $30 \%$ in the total cost of the MAS and a weight decrease of around $4 \%$.

\section{Acknowledgements}

The authors thank the support to this investigation by the Brazilian agencies: CNPq, CAPES and FAPERJ.

\section{References}

1. Callister WD Jr., Rethwish DG. Materials Science and Engineering: An Introduction. $8^{\text {th }}$ ed. New York: John Wiley \& Sons; 2010 .

2. Mohanty AK, Misra M, Drzal LT. Sustainable Bio-Composites from Renewable Resources: Opportunities and Challenges 
in the Green Materials World. Journal of Polymers and the Environment. 2002;10(1-2):19-26.

3. Netravali AN, Chabba S. Composites get greener. Materialstoday. 2003;6(4):22-29.

4. Crocker J. Natural materials innovative natural composites. Materials Technology. 2008;23(3):174-178.

5. Monteiro SN, Lopes FPD, Ferreira AS, Nascimento DCO. Natural-fiber polymer-matrix composites: Cheaper, tougher, and environmentally friendly. JOM. 2009;61(1):17-22.

6. John MJ, Thomas S. Biofibers and biocomposites. Carbohydrate Polymers. 2008;71(3):343-364.

7. Monteiro SN, Lopes FPD, Barbosa AP, Bevitori AB, Silva ILA, Costa LL. Natural Lignocellulosic Fibers as Engineering Materials - An Overview. Metallurgical and Materials Transactions A. 2011;42:2963.

8. Faruk O, Bledzki AK, Fink HP, Sain M. Biocomposites reinforced with natural fibers: 2000-2010. Progress in Polymer Science. 2012;37(11):1555-1596.

9. Thakur VK, Thakur MK, Gupta RK. Review: Raw Natural Fiber-Based Polymer Composites. International Journal of Polymer Analysis and Characterization. 2014;19(3):256-71.

10. Pappu A, Patil V, Jain S, Mahindrakar A, Haque R, Thakur VK. Advances in industrial prospective of cellulosic macromolecules enriched banana biofibre resources: A review. International Journal of Biological Macromolecules. 2015;79:449-458.

11. Güven O, Monteiro SN, Moura EAB, Drelich JW. Re-Emerging Field of Lignocellulosic Fiber - Polymer Composites and Ionizing Radiation Technology in their Formulation. Polymer Reviews. 2016;56(4):702-536.

12. Holbery J, Houston D. Natural-fiber-reinforced polymer composites applications in automotive. JOM. 2006;58(11):8086.

13. Zah R, Hischier R, Leão AL, Braun I. Curauá fibers in the automobile industry - a sustainability assessment. Journal of Cleaner Production. 2007;15(11-12):1032-1040.

14. Thomas N, Paul SA, Pothan LA, Deepa B. Natural Fibers: Structure, Properties and Applications. In: Kalia S, Kaith BS, Kaur I, eds. Cellulose Fibers: Bio- and Nano-Polymer Composites. Berlin, Heidelberg: Springer- Verlag; 2011. p. $3-42$.

15. Ali A, Shaker ZR, Khalina A, Sapuan SM. Development of Anti-Ballistic Board from Ramie Fiber. Polymer-Plastics Technology and Engineering. 2011;50(11):622-634.

16. Wambua P, Vangrimde B, Lomov S, Verpoest I. The response of natural fibre composites to ballistic impact by fragment simulating projectiles. Composite Structures. 2007;77(2):232240 .

17. Abidin MHZ, Mohamad MAH, Zaidi AMA, Mat WAW. Experimental Study on Ballistic Resistance of Sandwich Panel Protection Structure with Kenaf Foam as a Core Material against Small Arm Bullet. Applied Mechanics and Materials. 2013;315:612-615.

18. Luz FS, Lima Junior EP, Louro LHL, Monteiro SN. Ballistic Test of Multilayered Armor with Intermediate Epoxy Composite Reinforced with Jute Fabric. Materials Research. 2015;18(Suppl. 2):170-177.

19. Cruz RB, Lima Junior EP, Monteiro SN, Louro LHL. Giant Bamboo Fiber Reinforced Epoxy Composite in Multilayered Ballistic Armor. Materials Research. 2015;18(Suppl. 2):70-75.

20. Monteiro SN, Louro LHL, Trindade W, Elias CN, Ferreira CL, Lima ES, et al. Natural Curaua Fiber-Reinforced Composites in Multilayered Ballistic Armor. Metallurgical and Materials Transactions A. 2015;46(10):4567-4577.

21. Rohen LA, Margem FM, Monteiro SN, Vieira CMF, Araujo BM, Lima ES. Ballistic efficiency of an individual epoxy composite reinforced with sisal fibers in multilayered armor. Materials Research. 2015;18(Suppl. 2):55-62.

22. Monteiro SN, Milanezi TL, Louro LHL, Lima Jr EP, Braga FO, Gomes AV, et al. Novel ballistic ramie fabric composite competing with Kevlar $^{\mathrm{TM}}$ fabric in multilayered armor. Materials \& Design. 2016;96:263-269.

23. Monteiro SN, Braga FO, Lima Jr. EP, Louro LHL, Drelich JW. Promising curaua fiber-reinforced polyester composite. Polymer Engineering \& Science. 2016;57(9):947-954. DOI: $10.1002 /$ pen. 24471

24. U.S. Department of Justice; National Institute of Justice. NIJ 0101.06. Ballistic Resistance of Body Armor. Washington: U.S. Department of Justice; 2008.

25. Tasdemirci A, Tunusoglu G, Güden M. The effect of the interlayer on the ballistic performance of ceramic/composite armors: Experimental and numerical study. International Journal of Impact Engineering. 2012;44:1-9.

26. Shokrieh MM, Javadpour GH. Penetration analysis of a projectile in ceramic composite armor. Composite Structures. 2008;82(2):269-276.

27. Lee YS, Wetzel ED, Wagner NJ. The ballistic impact characteristics of $\operatorname{Kevlar} \circledast$ woven fabrics impregnated with a colloidal shear thickening fluid. Journal of Materials Science. 2003;38(13):2825-2833.

28. Jacobs MJN, Dingenen JLJV. Ballistic protection mechanisms in personal armour. Journal of Materials Science. 2001;36(13):31373142 .

29. Hachemane B, Zitoune R, Bezzazi B, Bouvet C. Sandwich composites impact and indentation behaviour study. Composites Part B: Engineering. 2013;51:1-10.

30. Monteiro SN, Lima Jr. EP, Louro LHL, Silva LC, Drelich JW. Unlocking Function of Aramid Fibers in Multilayered Ballistic Armor. Metallurgical and Materials Transactions A. 2015;46(1):37-40. 